\title{
GERIATRIC DEPRESSION AMONG RURAL AND URBAN SLUM COMMUNITY IN CHENNAI - A CROSS SECTIONAL STUDY
}

Balaji Arumugam, Saranya Nagalingam, Ravikumar Nivetha

1. Assistant Professor, Department of Community Medicine, A.C.S. Medical College and Hospital, Velappanchavadi, Chennai.

2. M.B.B.S. Student, A.C.S. Medical College and Hospital

3. M.B.B.S. Student, A.C.S. Medical College and Hospital

\section{CORRESPONDING AUTHOR}

Dr. Arumugam Balaji,

Assistant Professor,

Department of Community Medicine,

A.C.S. Medical College and Hospital,

Velappanchavadi, Chennai - 600077

E-mail: dr.a.balaji@gmail.com

Ph: 00919840234857

BACKGROUND: Depression is the most common psychiatric disorder among the elderly which can manifest as major or minor depression. The community-based studies have revealed that the prevalence of depression in geriatric population in India varies between $13 \%$ and $25 \%$. In spite of quantum of this problem there are very few studies from India investigating geriatric depression and its associated risk factors. This study aimed to establish the prevalence, sociodemographic correlates and factors associated with geriatric depression in urban slum and rural communities in Chennai. METHODS: This study was done as a cross sectional study in the urban and rural field practice areas of ACS Medical College and Hospital among 60 years and above age group by house to house survey method using Geriatric Depression Scale during July and August 2011.All the houses in the urban and rural field practice areas were surveyed and those who fulfilled the eligibility criteria were interviewed after getting informed consent. The results were expressed in percentages and chi-square test was done to find out the association. RESULTS: Totally 173 study participants were interviewed and the prevalence was found to be $41.1 \%$ and $45.8 \%$ in urban and rural communities respectively. Geriatric depression is significantly associated with female sex, living without spouse, illiteracy, time spent with children and grand children and dietary habits in both communities but money dependence and health problems were strongly associated with depression in urban community. CONCLUSION: The prevalence of depression in the elderly population in our study was moderately high in both areas and a cause of concern.

KEY WORDS: Geriatric depression, socio-demographic factors, money dependence, Geriatric depression score.

INTRODUCTION: Ageing is a natural process associated with: Physical, Biological and Psychological changes. Elderly population aged 60 years and above in the world will reach 1.2 billion by the year 2025 , the majority of whom will be in developing countries ${ }^{1}$. The proportion of elderly persons in the population of India raised from 5.63 per cent in 1961 to 6.58 per cent in 1991 and to 7.5 per cent in 20012. A high prevalence of mental disorders is seen in old age. Predominant among these is "Depression", which is an affective illness characterized by depressive in mood, cognition and behaviour3. "GERIATRIC DEPRESSION" is a common clinical 
condition in which "A prolonged state of mental depression in anyone over the age of 60 years". Community-based mental health studies have revealed that the point prevalence of depressive disorders among the geriatric population in India varies between 13 and $25 \%{ }^{4}$, 5. Though depression is the commonest mental health problem in old age, very few community-based studies have been conducted in India to understand the problem.

\section{AIMS AND OBJECTIVES:}

1. To estimate the prevalence of Geriatric Depression among 60 years and above individuals.

2. To study the socio-demographic correlates and pattern of Geriatric Depression.

3. To find out the factors associated with Geriatric Depression like: History of any chronic illnesses, Gender, Living without Spouse, Money Dependence and Time spent with Children and Grandchildren, Dietary Habits, etc.

MATERIALS AND METHODS: The study was conducted as a community based cross sectional study among 60 years and above age group residing in the field practice areas namely Adayalampattu and Parivakkam of ACS Medical College and Hospital, Chennai in between July $4^{\text {th }}$ and August 31st, 2011. Urban field practice area has approximately 2000 houses and rural field practice area has approximately 2500 houses. "House to House Survey" was done in both the areas. The people who were aged 60years and above were selected as our Study participants after getting informed consent. Our study excluded the individuals above 60years with the following criteria: Stroke with Aphasia, Loss of Hearing and those who were affected with loss of memory. The study tool which we had used was questionnaire which had two parts, one with general informations like socio-demographic profile, risk factors of geriatric depression. The second part of the questionnaire was Geriatric Depression Scale ${ }^{6}$ (GDS), first created by Yesavage et al., has been tested and used extensively with the older population. The GDS was found to have $92 \%$ sensitivity and $89 \%$ specificity when evaluated against diagnostic criteria. The GDS may be used with healthy, medically ill and mild to moderately cognitively impaired older adults. GDS Screens for seven characteristics of depression in elderly, which are Somatic Concern, Lower Affect, Cognitive Impairment, Feelings of Discrimination, Impaired Motivation, Lack of Future Orientation and Lack of Self-esteem ${ }^{7}$. According to this scale, scores between - 0 - 9 will be considered as Normal, 10-19 is mildly Depressive and 20-30 Severely Depressive. The data were analyzed with Epi-info software Version 3.5.1(2008) and Chi-square test was used as the test of significance.

RESULTS: Out of total 173 study participants 90 were from urban slum (Adayalampattu) and 83 from rural area (Parivakkam). In both urban slum and rural areas the female gender constituted $67 \%$ (116), majority of them belonged to 60 to 69 years of age that is $70 \%$ (63) from urban slum and 59\% (49) from rural areas. Sixty three percent (57) from urban slum and 68.6\% (57) from rural areas were illiterates and most of them among the study participants 78 $(86.7 \%)$ of urban slum and $69(83 \%)$ of rural areas were in Class V socioeconomic status. Sixty seven percent (60) from urban slum and 59\% (49) of rural population were living singly without spouse because of death. Among the study participants $31 \%$ from both the areas were not dependent on their children or others for money. 48.8\% (44) from urban and 50.6\% (42) from rural said that the time spent with their children and grandchildren were insufficient. The study participants from urban slum and rural areas showed 62.2\% (56) and 78.3\% (65) of multi 
system problem in the body and very few from both areas showed no morbidity. The prevalence of depression was found to be $41 \%$ (37) from urban slum and $46 \%$ (38) from rural area (table 1) . In our study geriatric depression was significantly associated with: female sex (0.0136), living without spouse $(0.0214)$, Illiteracy $(0.015)$, insufficient time spent with children and grandchildren (0.0209), irregular dietary habits (0.0004) and those who are economically dependent (0.0431) on their children in urban slum community. The rural community showed female sex (0.0597), living without spouse (0.0004), Illiteracy (0.0046), insufficient time spent with children and grandchildren (0.0000) and irregular dietary habits (0.0003). Our study results showed that socioeconomic status, health problems and sleep disturbance were not significantly associated with depression in both rural and urban slum community as given in the table 2 and 3.

DISCUSSION: The results of this study revealed that approximately $41 \%$ and $46 \%$ of elderly population were suffering from severe depression according to this Geriatric depression scale which is used for the assessment. This seems to be on much higher (almost twice) side when compared to the World Health Organization estimated overall prevalence rate of depressive disorders among the elderly generally varies between $10 \%$ and $20 \%$, depending on the cultural situations ${ }^{8}$. But the recent retrospective study of various 75 original research reports conducted between 1995 and 2005 which included only community based cross sectional surveys of $4,87,275$ elderly individuals, in the age group of 60 years and above, residing in various parts of the world revealed that the median prevalence rate of depressive disorders in the world was determined to be $10.3 \%$ and among the Indian elderly population was found to be $21.9 \% 9$. As far as the risk factors are concerned our study results showed that female gender, living alone without spouse, illiteracy, economic dependence, irregular dietary habits, insufficient time spent with children and grandchildren but surprisingly the factors like suffering multiple health problems, sleep disturbances and advancing age were not associated with the depression. Similar study conducted in urban slum of Mumbai concluded that depressed elderly (using GDS) constituted $45.9 \%$ of the study population which is on par with our study results and the significant variables associated with depression were poor socioeconomic status, marital status, non working or dependency, and illiteracy ${ }^{10}$. The study conducted at Pune among 202 elderly persons showed $19.36 \%$ prevalence of depression and was associated with female sex, single/widowed/separated status, staying in nuclear families, economic dependence on others and co-morbid physical illnesses ${ }^{11}$ and a study at Vellore revealed low income, history of cardiac illness, past head injury and diabetes increased the risk of depression among elderly ${ }^{12}$.

CONCLUSION: The prevalence of depression in the elderly population in our study was moderately high in both areas and a cause of concern. It is important to screen elderly persons for depression in order to determine the true prevalence of the condition and health systems must be geared up to play a greater role in early detection and prevention of "Geriatric Depression" using such screening tools.

\section{REFERENCES:}

1. Arokiasamy JT. Malaysia's Ageing Issues (Editorial). Med J Malaysia 1997; 52: 197-201.

2. Irudaya Rajan. S PhD,Population ageing and Health in India. The Centre for Enquiry into Health and Allied Themes (CEHAT), Mumbai. July - 2006. 
3. Burke MM, Laramie JA. Primary care of the older adult. $1^{\text {st }}$ Edition. USA: Mosby Inc, 2000.

4. Nandi DN, et al. The Incidence of mental disorders in one year in a rural community in West Bengal. Indian J Psychiatry 1976;18:79-87.

5. Ramachandran V, et al .Socio-cultural factors in late onset depression. Indian J Psychiatry 1982;24:268-73.

6. Yesavage, J.A., et al (1983). Development and Validation of a Geriatric Depression Screening Scale: A Preliminary Report. Journal of Psychiatric Research, 17, 37-49.

7. Sherina $\mathrm{M}$, et al ; The prevalence of depression among elderly in an urban area of Selangor, Malaysia; The International Medical Journal Vol.4 No 2 Dec 2005.

8. Rangaswamy SM. Geneva, Switzerland: The World Health Organization; 2001. World Health Report: Mental Health: New understanding New Hope.

9. Ankur Barua, et al. Prevalence of depressive disorders in the elderly. Ann Saudi Med. 2011 Nov-Dec; 31(6): 620-624.

10. Jain. R.K, Aras. R.Y - Depression in Geriatric Population in Urban Slums of Mumbai. Indian Journal of Public Health Vol.51 No.2 April - June, 2007)

11. K. Seby, Suprakash Chaudhury, and Rudraprosad Chakraborty, Prevalence of psychiatric and physical morbidity in an urban geriatric population. Indian J Psychiatry. 2011 AprJun; 53(2): 121-127

12. A. P. Rajkumar et al. Nature, prevalence and factors associated with depression among the elderly in a rural south Indian community. Int Psychogeriatr. 2009 April; 21(2): 372-378.

Table - 1 Distribution of Geriatric depression among rural and urban community

\begin{tabular}{|l|l|l|}
\hline Prevalence of depression & Rural (n = 83) & Urban slum (n = 90) \\
\hline Normal & $17(20.4 \%)$ & $18(20 \%)$ \\
\hline Mild depression & $28(33.8 \%)$ & $35(38.9 \%)$ \\
\hline Severe depression & $38(45.8 \%)$ & $37(41.1 \%)$ \\
\hline Total & $83(100 \%)$ & $90(100 \%)$ \\
\hline
\end{tabular}


Table - 2 Distribution of factors versus geriatric depression (rural community)

\begin{tabular}{|c|c|c|c|c|c|}
\hline \multirow{4}{*}{\begin{tabular}{|l|} 
Variable \\
Age group \\
60 to 69 \\
More than 70
\end{tabular}} & \multicolumn{3}{|c|}{$\begin{array}{l}\text { Rural community }(n=83) \\
\text { With GDS score classified as normal, mild } \\
\text { and severe depression }\end{array}$} & \multirow{4}{*}{\begin{tabular}{|l|}
$\begin{array}{l}\text { Chi }- \\
\text { square } \\
\text { value }\end{array}$ \\
0.6007 \\
\end{tabular}} & \multirow{4}{*}{\begin{tabular}{|l|} 
P value \\
$\begin{array}{l}0.7406 \\
\text { (NS) }\end{array}$ \\
\end{tabular}} \\
\hline & Mild & Normal & Severe & & \\
\hline & 18 & 9 & 22 & & \\
\hline & 10 & 8 & 16 & & \\
\hline \multirow{3}{*}{$\begin{array}{l}\text { Appetite } \\
\text { Normal } \\
\text { Reduced }\end{array}$} & Mild & Normal & Severe & \multirow[t]{3}{*}{8.5237} & \multirow{3}{*}{$\begin{array}{l}0.0141 \\
(S)\end{array}$} \\
\hline & 18 & 14 & 16 & & \\
\hline & 10 & 3 & 22 & & \\
\hline \multirow{3}{*}{$\begin{array}{l}\text { Dietary habits } \\
\text { Irregular } \\
\text { Regular }\end{array}$} & Mild & Normal & Severe & \multirow[t]{3}{*}{16.0527} & \multirow{3}{*}{$\begin{array}{l}0.0003 \\
(\mathrm{HS})\end{array}$} \\
\hline & 10 & 3 & 27 & & \\
\hline & 18 & 14 & 11 & & \\
\hline \multirow{3}{*}{$\begin{array}{l}\text { Education } \\
\text { Illiterate } \\
\text { Some schooling } \\
\end{array}$} & Mild & Normal & Severe & \multirow[t]{3}{*}{\begin{tabular}{|l|}
10.7553 \\
\end{tabular}} & \multirow{3}{*}{$\begin{array}{l}0.0046 \\
(\mathrm{HS})\end{array}$} \\
\hline & 15 & 9 & 33 & & \\
\hline & 13 & 8 & 5 & & \\
\hline \multirow{3}{*}{$\begin{array}{l}\text { Health problems } \\
\text { Single or nil problem } \\
\text { Multiple problems }\end{array}$} & Mild & Normal & Severe & \multirow[t]{3}{*}{5.4217} & \multirow{3}{*}{$\begin{array}{l}0.0665 \\
(\mathrm{NS})\end{array}$} \\
\hline & 8 & 6 & 4 & & \\
\hline & 20 & 11 & 34 & & \\
\hline \multirow{3}{*}{$\begin{array}{l}\text { Living } \\
\text { With spouse } \\
\text { Without spouse }\end{array}$} & Mild & Normal & Severe & \multirow[t]{3}{*}{15.4378} & \multirow{3}{*}{$\begin{array}{l}0.0004 \\
(\mathrm{HS})\end{array}$} \\
\hline & 13 & 13 & 8 & & \\
\hline & 15 & 4 & 30 & & \\
\hline \multirow{3}{*}{$\begin{array}{l}\text { Money dependence } \\
\text { No } \\
\text { Yes }\end{array}$} & Mild & Normal & Severe & \multirow[t]{3}{*}{1.1166} & \multirow{3}{*}{$\begin{array}{l}0.5722 \\
\text { (NS) }\end{array}$} \\
\hline & 8 & 4 & 14 & & \\
\hline & 20 & 13 & 24 & & \\
\hline \multirow{3}{*}{$\begin{array}{l}\text { Sex } \\
\text { Male } \\
\text { Female }\end{array}$} & Mild & Normal & Severe & \multirow[t]{3}{*}{5.6370} & \multirow{3}{*}{$\begin{array}{l}0.0597 \\
(\mathrm{NS})\end{array}$} \\
\hline & 10 & 9 & 8 & & \\
\hline & 18 & 8 & 30 & & \\
\hline \multirow{3}{*}{$\begin{array}{l}\text { Socioeconomic } \\
\text { status } \\
\text { Class III and IV } \\
\text { Class V }\end{array}$} & Mild & Normal & Severe & \multirow[t]{3}{*}{2.4177} & \multirow{3}{*}{$\begin{array}{l}0.2985 \\
(\mathrm{NS})\end{array}$} \\
\hline & 7 & 3 & 4 & & \\
\hline & 21 & 14 & 34 & & \\
\hline Sleeping pattern & Mild & Normal & Severe & 2.3058 & 0.3157 \\
\hline Normal & 18 & 13 & 21 & & (NS) \\
\hline Reduced & 10 & 4 & 17 & & \\
\hline Occupation & Mild & Normal & Severe & 3.6346 & 0.1625 \\
\hline Going for some job & 7 & 3 & 3 & & (NS) \\
\hline At home & 21 & 14 & 35 & & \\
\hline $\begin{array}{l}\text { Time spent with } \\
\text { children and grand }\end{array}$ & Mild & Normal & Severe & 27.2498 & $\begin{array}{l}0.0000 \\
(\mathrm{HS})\end{array}$ \\
\hline children & 17 & 16 & 8 & & \\
\hline $\begin{array}{l}\text { Sufficient } \\
\text { Insufficient }\end{array}$ & 11 & 1 & 30 & & \\
\hline
\end{tabular}


Table - 3 Distribution of factors versus geriatric depression (Urban slum community)

\begin{tabular}{|c|c|c|c|c|c|}
\hline Variable & $\begin{array}{l}\text { Urba } \\
\text { With } \\
\text { and } s\end{array}$ & $\begin{array}{l}\text { munity } \\
\text { classified } \\
\text { ession }\end{array}$ & rmal, mild & $\begin{array}{l}\text { Chi - } \\
\text { square } \\
\text { value }\end{array}$ & P value \\
\hline Age group & Mild & Normal & Severe & 0.6568 & 0.7201 (NS) \\
\hline 60 to 69 & 24 & 14 & 25 & & \\
\hline More than 70 & 11 & 4 & 12 & & \\
\hline Appetite & Mild & Normal & Severe & 10.4504 & $0.0054(\mathrm{HS})$ \\
\hline Normal & 21 & 16 & 16 & & \\
\hline Reduced & 14 & 2 & 21 & & \\
\hline Dietary habits & Mild & Normal & Severe & 15.8934 & $0.0004(\mathrm{HS})$ \\
\hline Irregular & 21 & 3 & 27 & & \\
\hline Regular & 14 & 15 & 10 & & \\
\hline Education & Mild & Normal & Severe & 8.4055 & 0.015 (HS) \\
\hline Illiterate & 21 & 7 & 29 & & \\
\hline Some schooling & 14 & 11 & 8 & & \\
\hline Health problems & Mild & Normal & Severe & 4.93 & 0.085 (NS) \\
\hline Single or nil problem & 16 & 9 & 9 & & \\
\hline Multiple problems & 19 & 9 & 28 & & \\
\hline Living & Mild & Normal & Severe & 7.688 & $0.0214(\mathrm{~S})$ \\
\hline With spouse & 13 & 10 & 7 & & \\
\hline Without spouse & 22 & 8 & 30 & & \\
\hline Money dependence & Mild & Normal & Severe & 6.2893 & $0.0431(\mathrm{~S})$ \\
\hline No & 9 & 10 & 9 & & \\
\hline Yes & 26 & 8 & 28 & & \\
\hline Sex & Mild & Normal & Severe & 8.5909 & $0.0136(\mathrm{~S})$ \\
\hline Male & 11 & 11 & 8 & & \\
\hline Female & 24 & 7 & 29 & & \\
\hline Socioeconomic & Mild & Normal & Severe & 1.2359 & 0.5391 (NS) \\
\hline status & 5 & 1 & 6 & & \\
\hline $\begin{array}{l}\text { Class III and IV } \\
\text { Class V }\end{array}$ & 30 & 17 & 31 & & \\
\hline Sleeping pattern & Mild & Normal & Severe & 2.7909 & 0.2477 (NS) \\
\hline Normal & 19 & 14 & 23 & & \\
\hline Reduced & 16 & 4 & 14 & & \\
\hline Occupation & Mild & Normal & Severe & 7.8018 & $0.0202(\mathrm{~S})$ \\
\hline Going for some job & 8 & 10 & 8 & & \\
\hline At home & 27 & 8 & 29 & & \\
\hline Time spent with & Mild & Normal & Severe & 7.7327 & $0.0209(\mathrm{~S})$ \\
\hline $\begin{array}{l}\text { chiraren ana grana } \\
\text { children }\end{array}$ & 18 & 14 & 14 & & \\
\hline $\begin{array}{l}\text { Sufficient } \\
\text { Insufficient }\end{array}$ & 17 & 4 & 23 & & \\
\hline
\end{tabular}


Figure - 1

\section{Prevalence of depression among rural population}

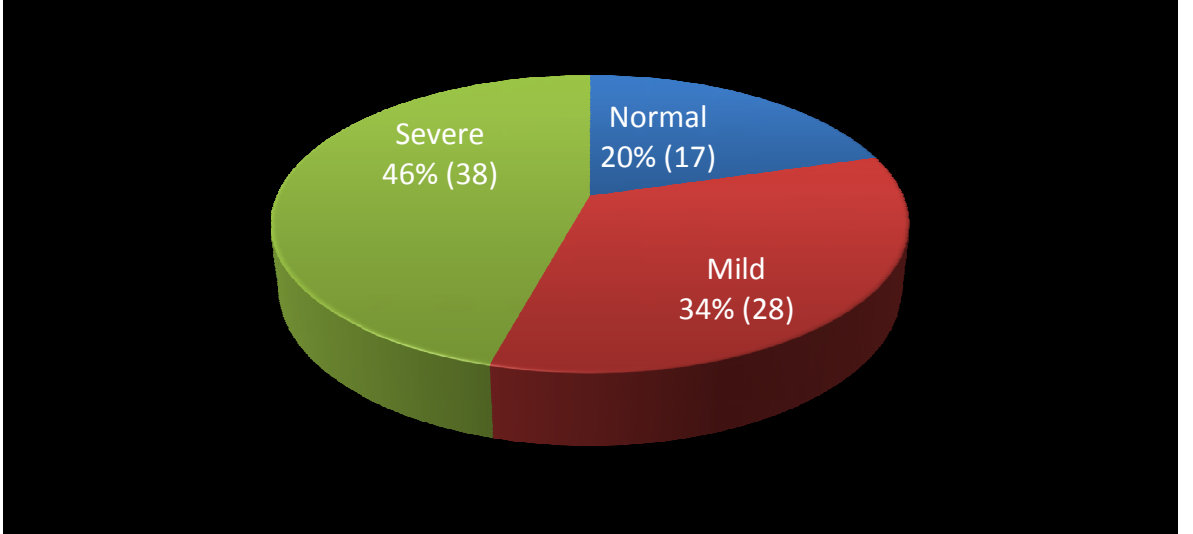

Figure - 2

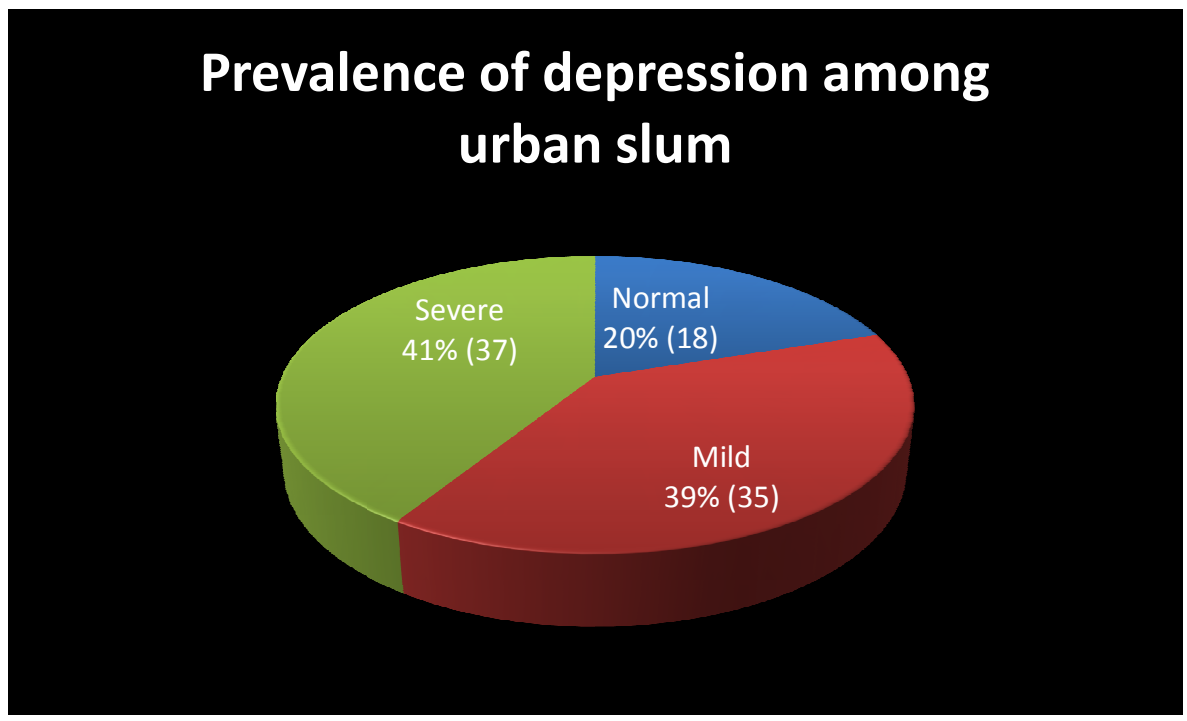

